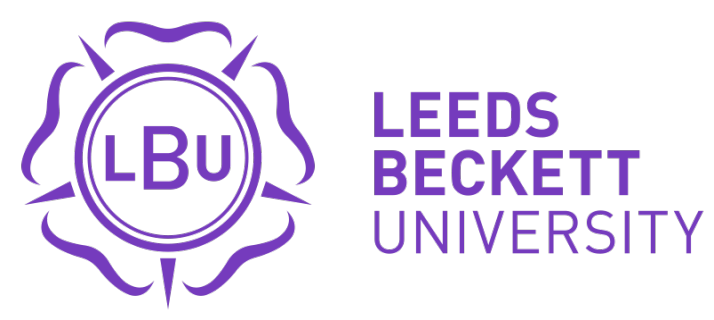

Citation:

Cockcroft, T (2007) Police culture(s): some definitional, methodological, contextual and analytical considerations. In: Police Occupational Culture: New Debates and Directions. Sociology of Crime, Law and Deviance, Vol. 8 . Emerald Group Publishing, pp. 85-102. ISBN 9780762313075 DOI: https://doi.org/10.1016/s1521-6136(07)08003-7

Link to Leeds Beckett Repository record:

https://eprints.leedsbeckett.ac.uk/id/eprint/8229/

Document Version:

Book Section (Accepted Version)

Creative Commons: Attribution-Noncommercial 4.0

The aim of the Leeds Beckett Repository is to provide open access to our research, as required by funder policies and permitted by publishers and copyright law.

The Leeds Beckett repository holds a wide range of publications, each of which has been checked for copyright and the relevant embargo period has been applied by the Research Services team.

We operate on a standard take-down policy. If you are the author or publisher of an output and you would like it removed from the repository, please contact us and we will investigate on a case-by-case basis.

Each thesis in the repository has been cleared where necessary by the author for third party copyright. If you would like a thesis to be removed from the repository or believe there is an issue with copyright, please contact us on openaccess@leedsbeckett.ac.uk and we will investigate on a case-by-case basis. 
TITLE: POLICE CULTURE(S): SOME DEFINITIONAL, METHODOLOGICAL AND ANALYTICAL CONSIDERATIONS

AUTHOR: DR TOM COCKCROFT, DEPARTMENT OF CRIME AND POLICING STUDIES, CANTERBURY CHRIST CHURCH UNIVERSITY 


\begin{abstract}
Police Culture(s): Some Definitional, Contextual and Analytical Considerations

This chapter will explore the use of oral histories in furthering our understanding of police cultures by expanding upon three main themes. First, the oral history approach challenges us in terms of the need to differentiate between police organizational influences and the influences of wider society. Second, the approach highlights the difficulties associated with assuming a degree of universality between police cultures. Third, the approach allows one to build upon the work of Shearing and Ericson (1991) and Waddington (1999) in drawing out further dimensions of the problematic relationship between language and behaviour in the context of police narratives.
\end{abstract}

\title{
REFERENCES
}

Shearing, C. and Ericson, R. (1991) 'Culture as Figurative Action', British Journal of Sociology, 42 (4), 481-506

Waddington, P.A.J. (1999) 'Police (canteen) sub-culture: an appreciation', British Journal of Criminology, 39 (2), 286-309 
Police culture is, in many respects, a contested term. Inter alia it can refer to specific (and almost prescriptive) modes of behaviour, the values that inform such behaviours and the narrative modes used by the police to describe or accommodate them. The purpose of this chapter is to highlight some of those definitional, methodological and analytical issues which emerge when one explores police culture through the oral history method. This chapter will aim to highlight the contribution of oral history to debates concerning the clarity of the term police culture (given its expansiveness and with regard to changes to the policing context in recent years), the use of oral history in exploring police culture and, finally, the challenges of making sense of police testimony. Prior to an analysis of these three thematic areas, a brief overview of oral history will be presented.

\section{WHAT IS ORAL HISTORY?}

Oral history is a broad-based methodological approach that focuses upon the narratives of individuals recounting past experiences. Several of the definitions of oral history provided by the existing literature highlight disputes over its purpose and method. For example, the Library of Congress (1971) states that oral history is, simply, information in oral form collected through planned interviews, a definition that fails to acknowledge that oral histories have both an explicit historical dimension and can be based upon spontaneous exchanges that really do not constitute 'planned' interviews as such. Grele (1996, p.63) views oral history as "the interviewing of eyewitness participants in the events of the past for the purposes of historical construction" a definition that effectively describes some oral history projects but does not adequately portray those studies that are concerned with meaning rather than 
events (see Portelli, 1991, for a fuller discussion on this point). Given the disputed nature of what constitutes oral history, it is perhaps of use to present the broad but helpful definition provided by Starr $(1977, \mathrm{p} .440)$ that suggests that, "...Oral history is primary source material obtained by recording the spoken words - generally by means of planned tape-recorded interviews - of persons deemed to harbour hitherto unavailable information worth preserving".

Recent years, as Perks and Thomson (1998) note, have seen a renewed interest in oral history on account of the growing interest in emergent qualitative approaches such as life history. This, and the growing acknowledgement of oral history as an interdisciplinary tool, has served to, perhaps paradoxically, allow the method to weaken its links with history (where, as Sangster, 1994 notes, it was seen by some as too unhistoric) and to reposition itself as a qualitative method of enquiry. Given that biographical approaches such as oral history have strong links with the symbolic interactionist 'schools' of sociology (Goodey, 2000) as well as with the socialist movement (for example, Popular Memory Group (1982) and Selbourne (1980)) oral history has developed as a means of addressing the lives of those generally neglected by more orthodox historical approaches. In this way, oral history has provided a suitable way of addressing the hidden histories of groups such as rural women in South Africa (Bozzoli, 1991), labourers in 1930s Hackney (Hackney WEA, (1975) gay men and women (Kennedy, 1995) and the disabled (Walmsley, 1995).

\section{DEFINITIONAL CONSIDERATIONS}


One of the challenges of making sense of police culture is that from a seemingly straightforward precept, that police officers have distinct and occupationally-related styles of behaviour and opinion, a seemingly endless array of reverberations can be felt. For example, by taking three straightforward explanations of police culture a large number of avenues of inquiry further become apparent:

"a layer of informal occupational norms and values operating under the apparently rigid hierarchical structure of police organisations" Chan (1997, p. 43)

"accepted practices, rules, and principles of conduct that are situationally applied, and generalized rationales and beliefs"

(Manning 1989, p. 360)

"a patterned set of understandings which help to cope with and adjust to the pressures and tensions which confront the police"

Reiner (1992, p.109)

From three clear definitions, therefore, one is confronted with notions of informality within formal organisations; the situational application of beliefs; and the need for a cognitive lens within which to interpret the tensions which are integral to the job. Despite the symbiotic relationship between such themes one is immediately struck by the vast range of potential impacts of such a starting point. Unsurprisingly, such broad definitions can be seen as unhelpful in some quarters, as is evidenced by the following extract from HMIC: 
"The journalistic shorthand that summarises the thinking of operational police officers as being explained by "a canteen culture" is as misleading as it is mischievous. It is acknowledged that the location reference is merely evocative of what is seen as a collective attitude. These very canteens witness the conversations of officers who still see service to all members of the public as an intrinsic part of their vocation. The number of officers who are nominated each year for community awards are part of this same culture" (1999, p. 29)

The complexity of organisational cultures, their nature and effect is made especially difficult when applied to the concept of policing. Primarily, the police are historically characterised as having a role that is difficult to define (a theme common to public sector institutions). Goldstein (1979) noted that there is a disparity between what the public perceive the police function as and what it is that the police actually do. Goldstein (1979), therefore, differentiates between the widely-held view that the police are there to enforce the law and a contrasting view that the police enforce laws as a mere means of achieving their main goal - quite simply, solving problems. Such an approach was anticipated by Westley (1970) who drew on the work of Vollmer (1936) to show that there is a difference between the explicitly-stated responsibilities of the police and that work that they actually undertake. Beyond such principal tasks and responsibilities lie the more social or service-oriented aspects of the police role and, significantly, these are subject to variation between areas and over time. Increasingly, historical analyses of police work (see, for example, Brogden, 1991) demonstrate the ways in which the behaviours of officers within a particular force are 
unavoidably related to historically-located industrial structures, employment patterns and the resultant secondary economies. One such example is provided by Emsley (2005) in his analysis of the Sergeant Goddard ${ }^{1}$ case where he notes that the Soho area of London provided both the motivation and the opportunity for corrupt police behaviour with two main features accounting for this. The financial wealth of Soho at the time served to highlight the relative modesty of the police salary and, perhaps more importantly, much of the wealth of the area was generated through unlawful pursuits. Any analysis of police occupational culture, therefore, needs to acknowledge those features of the social environment that may increase the probability of, if not actively encourage, certain police responses.

Oral history is one method of enquiry that can facilitate our understanding of the complex relationships that exist between police officers and their wider social environments. Of particular note is the fact that police oral histories appear to have largely circumvented the four criticisms forwarded by Chan (1997) in her critique of more traditional analyses of police culture. For example, Chan's first criticism is that of ‘internal differentiation and jurisdictional differences' (1997, p. 65). Weinberger's (1995) oral history of policing adequately conveys both the way in which individual officers in the same station adopted contrasting values and behaviours as well as identifying considerable differences in police role between locations. In particular, in Weinberger's work, the issue of 'internal differentiation' is highlighted through her findings in regard to police use of force. For example, despite the routine use of force by some officers to gain confessions, assert authority and informally resolve public order situations, other officers in her sample condemned the use of force by officers as poor

\footnotetext{
${ }^{1}$ George Goddard, a Sergeant in the Metropolitan Police Force, was convicted of corruptly accepting money off members of the public in 1929
} 
police practice. Likewise, pronounced differences in policing between jurisdictions were evidenced by her comparison of rural and inner-city police divisions, with officers in the former priding themselves on the lack of 'action' that characterised their day to day work. In the latter, however, the pressure to be seen as efficient led to inner-city officers challenging neighbouring divisions to see who could generate the most arrests and summonses.

Chan's second criticism of traditional conceptions of police culture is that they portray police officers as being passively socialised into the culture of the police. Brogden's oral history of Liverpool policing between the First and Second World Wars goes some way towards highlighting alternative interpretations of the socialisation of officers. First, he suggests that the considerable amount of discretion enjoyed by officers allowed them to develop their own particular strategies for dealing with, for example, public order situations - a factor which perhaps undermines the notion that police officers, in all situations, have a prescriptive framework of reference for future action. Second, he suggests that the relative isolation of the beat officer's role simply did not allow for the sustained social immersion with one's colleagues which is required to prolong a strong occupational culture.

Chan further challenges traditional conceptions of police culture for neglecting the influence of wider external factors upon the context of policing. Weinberger (1995) provides an overview of one such external factor by assessing the impact of the Street Betting Act of 1906. Significantly, this one piece of legislation was viewed as having far-reaching consequences for day-to-day policing given its impact upon police relations with the public and the role it played in encouraging bribery of officers. Similarly, 
Weinberger (1995) unthreads the impact of wider organisational change during the 1960s which resulted in some areas undergoing a reversal of policy concerning the recording of crime, a move that subsequently led to CID officers being encouraged to record as much crime as possible. Over time, and as Weinberger illustrates, the advent of such policies had wide-ranging effects upon the CID in terms of their working practices, morale and relationship with uniformed officers.

Finally, Chan questions the extent to which cultural change is possible within a restrictive and deterministic cultural framework. Again, oral history approaches allow for an appreciation of cultural change within the police organisation. For example, Weinberger (1995) demonstrates how the exigencies of wartime signalled a remodelling of the police relationship with the public in terms which emphasised the service role of the police and the narratives which constitute Weinberger's oral history emphasise the public's appreciation of the work undertaken by the police at this time. Her work also describes how the advent of the post-war era heralded a swift decline in police relations with the public and, for the officers interviewed by Weinberger, the 1950's onwards were characterised by "strain and ambiguity" (1995, p. 133), a growing detachment from the public and significant changes to police strategy. Tellingly, the narratives from the officers of the 1930s and 1940s suggest that those officers were quick to censure postwar society and the style of policing that they saw as characterising it. Accordingly, such a distinction between pre- and post-war policing does suggest the possibility of considerable cultural change occurring over a relatively short period of time.

Oral history, therefore, allows for a reading of police culture which emphasises the possibility of cultural variation, the agency of the individual social actor, the impact of 
external factors and the possibility of cultural change. As Samuel (1976) notes, "People's memory of their work...is often particularly vivid, and extends to incidents and events and stories which give precious insights into the workplace, as a total context and cultural setting - the ambiguities of foremanship and the difficulties encountered by authority, the nature of the learning process, the sub-division of the different classes of work..." (p. 202). By focusing on the individual officer in relation to, "local and national specificity, intra-organizational conflicts, and processes of temporal change" (Loader and Mulcahy, 2003, p. 182) oral history provides a framework that encourages investigation of the ways in which police officers relate to the complex environments they inhabit.

Garland (2001) notes the profound changes in the context of criminal justice in recent years. The increasingly 'mixed economy' (2001, p.18) of policing has led, Garland claims, to a pervasive dissolution of institutional responsibility (a studied retreat from what Manning (1978a) viewed as the manufactured appearance of efficient crime control utilised by the police). Matravers and Maruna (2005) further note, with reference to Garland (2001), that such changes to the 'idea' of policing are implicitly connected to the increased normalisation of crime. This redefinition of crime suggests that models that view 'the police', 'the public' and the relationship between the two as static are failing to appreciate changes to our understanding of correlates of victimisation and the increasingly multi-agency nature of policing. Similarly, Loader and Sparks (2005) cogently note; 
"The 'new culture of control' is...composed of a diverse, contradictory array of situational technologies, policing styles, preventative strategies and modes of punishment, a complex conditioned by political and cultural sensibilities much more attuned to the notion of crime, and supported by a self-consciously sober, anti-social set of political and criminological ideas" (p.1)

Much research in the area of police culture has neglected to situate policing and it's attendant culture, or cultures, within an appropriate "social, political, legal and organisational context" (Chan, 1997, p. 67). That is, primacy is generally attributed to explanations of police behaviour where causality is given to factors distinctive to the organisation of policing. This is not to understate the impact that institutional factors have upon the behaviour, opinions and culture of police officers but to suggest that they should not be seen in isolation. It is not difficult to chart some apparent evidence for this tendency to view police culture as being largely the product of institutional factors.

Bittner (1967) saw police-public relations as being built upon a 'discrepancy' in the police role that emphasises both the need to enforce order and the need to foster relations with the community and Banton (1964) noted that this 'duality' (p.188) of the police role provides a logical foundation for the study of police relations with the public. Since the publication of Banton's work (wherein he voices concern for perhaps presenting police-public relations in too positive a light) we have generally seen analyses of police culture which concentrate on those features of the police role that emphasise law enforcement rather than service provision. By doing so we have 
focussed on policing as an act that is imposed rather than mediated and which, subsequently, fails to address a substantial part of the police role.

The pitfalls of investigating police culture without taking into account socio-political factors leads to a reading of policework that situates it in a sociological cul-de-sac devoid of sufficiently broad cultural appreciation - wider culture does not simply 'end' at the front door of the police station. Brogden (1991) provides an especially incisive account in this respect by drawing out the particular social, economic and cultural influences which characterised Liverpool in the first half of the $20^{\text {th }}$ century. He identifies the unquestionable influence of the city's economic infrastructure, built largely on its status as the largest seaport in Western Europe, as determining not only the class composition of the city but also its tradition of casual employment. Likewise, he describes the persistent undercurrent of tension between the police and ethnic minority groups in the city where a precursor to the 1981 Toxteth riots can be found in the 1919 race riots that the city witnessed. When we build into this picture a pronounced sectarian divide we become acutely aware that Liverpool was a city where the job of policing was inextricably linked to the social relations (and tensions) of that particular environment.

This unique social milieu shaped not only the views of police officers but also the way they policed. As Brogden (1982) illustrates, outside of London, Liverpool was the only key location to witness widespread police strikes during 1919 which, incidentally, led to widespread support from the public for the public police an occurrence that, in itself, highlights the "messy, [and] confused" (Brogden, 1991, p. 2) nature of class relations in the area. Likewise Brogden (1982) describes a police force 
that itself was strictly divided by stratifications of social class with officers from the middle-classes being overtly antagonistic to unions and their members. Brogden's work is crucial in this respect as it draws out the historical and cultural underpinnings that shape not only a given environment but which prescribe the nature of social relations within that locale. Conceptions of police culture which fail to take into account such distinct, yet complex, factors that provoke variations in police behaviour do little to acknowledge that police culture is, "neither monolithic nor unchanging" (Reiner, 2000, p.106) and characterised by a, "complexity and multi-faceted nature" (Foster, 2003, p.222).

One unfortunate consequence of approaches that fail to take into account the complexity of the context within which policing takes place is, according to Punch (1985), an over-eagerness to automatically view all police behaviours as artefacts of a specific and separate police culture. Punch (1985) continues by advocating methodological styles that incorporate, “...historical, comparative (cross-cultural and cross-national), and organizational levels of analysis" (p.186) to help us fully understand the shifting and nuanced nature of much police behaviour. In the following section, one particular form of historical analysis will be explored in respect of how it might be used to successfully investigate areas of police culture.

\section{NEW METHODOLOGICAL APPROACHES}

One way of demonstrating the impact of shifting political and social contexts upon police culture is to utilise methodological approaches that can accommodate the variable historical relations between the police and wider society. This is not to 
disregard the fact that there appear to be some relatively consistent cultural reference points in police work. Skolnick argues that police culture serves as a cultural lens through which to make sense of the world and it might be fair to suggest that, over time, the focus of the lens may vary, accentuating some attributes and diminishing others. Brown (1995) further notes that core assumptions which constitute a culture will tend to remain relatively stable whereas the more ancillary assumptions will be prone to transformation. Such a distinction suggests that we are likely to witness cultural shifts which emphasise certain roles or values as important at different periods of time and in different environments.

Traditionally, police culture has been viewed in terms that tend to gloss over many variations in police behaviour. Such an approach has allowed us to construct a conception of the police that highlights factors common to the police milieu but which fails to fully assimilate those factors that are not common to the occupational world of all officers. Accordingly, alternative methodologies and disciplinary approaches may serve to highlight the diversity of police experiences rather than the similarity. One example is the oral history technique as utilised by both Brogden (1991) and Weinberger (1995) which draw upon sociological and socio-historical approaches respectively. These accounts provide a vital dimension to our understanding of policing not only in a broader sense but especially in terms of understanding what police officers do and how they justify or explain their actions. In many respects, the narratives generated by oral history projects appear little or no different to police narratives generated by more contemporary research projects in that they provide vivid first-hand accounts of police officers recounting the 'reality' of day-to-day policing. Where they do differ, however, is in what they offer us as a hitherto 
unavailable glimpse of the lives of former police officers and do so within a format that allows us to understand the wider legal, political and social contexts of that time. As Perks and Thomson (1998) note, not only do oral histories alert researchers to new areas of interest but are additionally instilled with a subjectivity and personal value borne of experience and reflection.

The works of both Weinberger (1995) and Brogden (1991) do, however, have a wider purpose than merely 'filling in' gaps in our historical understanding of policing. Perhaps their greatest contributions has been in terms of both providing a voice to previously 'hidden' histories and in what they offer us in terms of understanding how police officers both comprehended and managed the social worlds that they inhabited. Both works demonstrate the importance of more recent histories of policing as a means of acknowledging both the considerable parallels and dissimilarities between the cultural dynamics of the past and the present.

These oral histories suggest that, historically, police behaviour was influenced by less formalised instruction and supervision than nowadays and that, subsequently, police officers used their considerable discretion to exhibit a wide variety of behaviours. Crucially, and where such work proves invaluable, is in the way that it allows officers not only to explain the actions they carry out or the values that they hold, but to contextualise these in terms of the pressures brought to bear upon them or, conversely, in terms of those aspects of their everyday lives which supported such actions or values. Both Brogden (1991) and Weinberger (1995) highlight use of force by police officers and show how it was used, variously, as a means of extracting confessions, asserting authority and a means of preempting further trouble. These oral histories succeed in not only explaining such types of 
behaviour and their extent but also in explaining the norms surrounding their use and how they became to be viewed as 'acceptable' by the police, and also sometimes, the public. Oral history, according to Weinberger (1995, p.3) therefore;

"offers a particular advantage, as an especially useful means of inquiry in bureaucratic and hierarchical organizations where the gap between the officially stated means and purposes, and the reality on the ground is likely to be wide"

Police oral histories point to the existence of possible alternative readings of police culture and its intensity, a point that may serve to partially reinforce Manning's (1978b) assertion that policing is not endowed with a common culture. Primarily, this is due to the broad nature of oral history narratives and the fact that the relatively un-structured interviews upon which they are based lead to a large amount of diverse data from which it is often hard to extract common experiences despite the existence of some apparently persistent cultural reference points. There is a real need for those undertaking police oral histories to engage with the challenges of using such narrative data appropriately as the conceptualisation of police narratives in terms that deny them their true complexity has, arguably, been one of the factors sustaining deterministic views of police culture. To equate language with action through a two-dimensional axis of cause and effect displays a lack of regard for the use of language as a creative tool that has different purposes in different situations. 
Genette (1980) draws out the complexities of narrative by suggesting that any narrative has a relationship with both the occurrence it presents and the act of narration itself. In short, to take a particular narrative and assume that it is a mere account of what happened, where and to whom is to ignore the subtleties of the form and purpose of language. Instead, we need to appreciate that the relationship between a narrative and an occurrence is not inherently unproblematic and, correspondingly, that the act of narration is in many instances a creative rather than a passive act.

Shearing and Ericson (1991) provide a sophisticated account of police 'storytelling' in their 'Culture as Figurative Action' model that draws on what Ericson, Baranek and Chan (1987) termed the 'vocabulary of precedents' which denotes the ways in which language provides a 'cultural tool-kit' (1991, p.500) for occupational behaviour. Crucially, Shearing and Ericson (1991) note that such police narration allows a degree of creativity and flexibility in police action and invites individuals to either be guided by or to extemporize within the provided framework. The sheer breadth of purpose presented by such storytelling invariably necessitates an appreciation of the inconsistent role and form of police language. As such, police language is portrayed in terms that emphasise its adaptive and versatile nature. Some police narrations, therefore, are viewed by Shearing and Ericson (1991) as short-lived, static and descriptive whereas others may be persistent, perpetually-evolving and subjective, the distinction between the two ultimately depending on the purpose which that testimony holds for the officer.

Such an account of the relationship between language and culture (or sub-culture) is obviously of wide interest to those engaged in police culture research not least for the way in which it appears to challenge overly-deterministic conceptions of the relationship between 
police behaviour and police culture. Shearing and Ericson's (1991) model has been criticised by other policing scholars who aim to clearly delineate between those cultural influences associated with police culture and those from wider societal culture. Waddington (1999) challenges Shearing and Ericson's model on a number of points, the first of which asks quite simply whether officers might be more influenced by those narratives which are generated outside of the culture of policing than those generated within it.

Perhaps Waddington's (1999) main contribution to the debate over police narratives is his suggestion that police culture might be bifurcated along the lines of a canteen culture and an operational culture. That is, the cultural rules which guide action on the street may be separate to those that guide the recounting of such actions amongst their peers. As Waddington (1999) shows, canteen storytelling can be a means of contextualising occupational experiences, a way of emphasising, and sustaining, the perceived 'them' and 'us' worldview of policing which disparages all who play down either the danger or the bureaucracy of the job. If the 'mean streets' are the battleground of policing, then as Waddington (1999, p.295) notes, "the canteen is the "repair shop"" and it is this distinction that raises some conspicuous challenges for research into policing. If canteen talk acts as a distorting lens through which officers accentuate their understanding of their work in relation to key cultural themes, just how 'valid' are such narratives to our understanding of what police officers actually 'do'?

Further questions surrounding the ways in which police officers 'use' language soon arise when one looks at the use of police oral history narratives. The analysis of narratives provided by retired police officers that pertain to incidents that occurred as far back as 60 years ago demand certain considerations and it is perhaps true to state that 
oral historians have been instrumental in drawing our attention to the nuances of occupationally-based narratives. Unsurprisingly, the issue of memory and its impact on the narrating of past incidents is a recurrent theme of discussion within the literature of oral history (Lummis, 1983, provides a detailed overview of these issues). Similarly, Frisch (1990), for example, draws attention to the concern that, even with regard to recall of the recent past, interviewees are liable to reflect upon their past experiences rather than recall their feelings at the time. The impact of hindsight (Seldon and Pappworth, 1983, p.25) remains a crucial issue that potentially can serve to remove a narrative from its original and personally-situated context.

This point is addressed by Beckford (1975) who highlights the impact of 'plausibility structures' which are used by social actors to assemble their normative view of the social world. Such 'plausibility structures' refer to institutions which provide the basis for an individual's worldview and which sustain meaning through language and ritual denied to others not affiliated to that particular group and, crucially, which provide a framework through which individuals both articulate meaning and are socialised. Reiner (1992, p.109) notes that police culture can be viewed in terms of, "a patterned set of understandings" which, one might speculate, broadly serves as a form of 'plausibility structure'. When one is removed from a particular 'plausibility structure' (through retirement, promotion or a change in occupational role or status within a force) we may need to consider the influence of that referential framework on subsequent narratives concerning that individual's past.

Furthermore, the study of police oral histories provides a potential historical angle to Shearing and Ericson's (1991) model of 'Culture as Figurative Action'. In the introduction to Weinberger's (1995) oral history of English policing, she notes that the analysis of police 
oral history narratives compel the researcher to confront the inevitable intertwining of allegory and social identity and to recognize the fact that narratives, “...tell us less about events than about their symbolic, cultural and personal meaning" (1995, p.3). A further factor that needs to be taken into account when assessing the narratives of those engaged in actions which occasionally might attract censure is that of the distinction between public and private memories. Thomson (1998) provides a case study of an Australian Anzac veteran recounting his recollections of the Battle of Gallipoli and charts how the recall and narrative representations of the past are mediated through public expectation and national mythology. Only with the passage of time and the influence of the anti-war movement has it become possible for Thomson's subject to recall the previously taboo subjects of tension between ranks and the hostility of many sections of the public to Anzac veterans on their return after the First World War.

We can speculate that this distinction between 'what actually happened' and 'what should have happened' might be an integral issue in our understanding of police narratives. Similarly, one might take such examples of individuals being reluctant to break with the prevalent discourses of the time as further evidence of the influence of external factors upon what individuals do and how they present such actions to 'outsiders'. As Susman (1964) notes, the dialectic tension between history and myth/ideology, "through combination and interaction...produce a variety of historical visions" (Grele, 1998, p.46) which are ultimately dependent upon the individual narrating, the subject they are narrating and who they are narrating to.

Such discrepancies do suggest a need to adopt approaches to understanding police narratives that draw away from simplistic methods that simply equate police language with police 
action. This complex relationship (already addressed by writers such as Waddington, 1999, and Shearing and Ericson, 1991) becomes even more intricate when one introduces a historical dimension. As Abbott (1991) implies, any true appreciation of social process requires an appreciation of the complexity of the changing environment in which those processes take place.

\section{CONCLUSION}

Police culture is a broad and often expansive term that can be used to refer to a collection of individual and/or collective attributes and which can be investigated through a number of disciplinary lenses. Narayanan (2005) notes that the study of police culture is often linked to a reformist strand of sociology that concerns itself with the relationship between police behaviour and due process. In short, the prevailing logic within much sociological/criminological research appears to be that poor police practice must have a cultural explanation ergo police culture must, essentially, be negative ${ }^{2}$. Alternatively, MacAlister (2004) draws on contemporary literature into occupational stress (eg Van Patten and Burke, 2001) to illustrate how police culture may serve a positive function within the police arena ${ }^{3}$. He views the culture of the police as providing a support mechanism that allows officers to deal with the stress associated with parts of the role in a way that is removed from wider civilian life. This suggests that the area of police culture would benefit from research grounded in different disciplines within the social sciences to provide a more

\footnotetext{
${ }^{2}$ Nevertheless, van der Spuy (2006) in her review of two recent publications on South African policing (Marks, 2005; Altbeker, 2005) commends the authors for offering appreciative ethnographic examinations of their subject matter which succeed in contextualising policing in terms of wider societal forces.

${ }^{3}$ Similarly, a police force Chaplain recently published an article entitled "Thank God for police culture" (Beal, 2001) in which he extolled the need for officers to preserve their sense of a professional community which he perceived as being eroded by the rise of individualism.
} 
rounded analysis of not only the nature and extent of police cultures but also their actual utility to officers.

Police oral histories raise a number of interesting angles which might benefit future research in the area of police culture namely in terms of the influence of internal and external factors and the interpretation of narratives. The historical dimension provided through such narratives allows us to appreciate the impact of factors such as responses to police scandals, the demographic factors peculiar to an area and the negotiated 'relationships' between the police and those likely to be on the receiving end of police authority. By extracting the "undercurrents, inconsistencies and quirks" (Fielding, 1997) of police officers' working lives they also provide explanations of 'why' officers act in the way they do rather than merely explain 'how' they act. Punch's (1985) contention that too much emphasis is placed upon the power of internal factors suggests that until we more fully appreciate research methodologies that allow us to examine policework within contexts which acknowledge the influence of wider societal factors it is unlikely that this dialectic will be resolved.

The role of narrative and its importance to our understanding of police culture appears as an interesting but largely ignored area in many analyses. Recent years have seen the literature of oral history acknowledge the challenges of the spoken word and the complexity of its relationship to action, primarily due to its reliance on relatively unstructured interviewing methods. Barring the work of Shearing and Ericson (1991) and Waddington (1999) surprisingly little has been written on the specific area of police narrative. As Waddington (1999) notes, ethnographers engaged in studies of policing have been reluctant to suggest that the relationship between police narrative and 
behaviour is unproblematic. Notwithstanding the obvious methodological challenges of unthreading the complexities of such an entwined relationship, it stands to reason that the acknowledgement of the "interpretive and active role" (Chan, 1997, p. 66) of individual officers in making sense of their environment should be replicated in an acknowledgement of their fluid and constructive use of language.

This chapter has attempted to address some concerns regarding what we mean by the term police culture, the opportunities provided by the oral history method and some of the challenges of making sense of police testimony. In doing so, there is always a danger of being seen to promote a negative and problematic view of police culture that questions the value of further investigation. This is by no means the intention of this chapter. Instead, such challenges should be used to enrich and inform our future research in this area. The need for further debate concerning what we mean by the term 'police culture' is perhaps timely regardless of issues of methodology. Newburn (2003), in particular, provides a coherent overview of the changes to both the police and policing which are currently taking place whilst simultaneously reminding us that key aspects of the police role remain unchanged. Such an analysis suggests that the roles of untangling the cultural dynamics of policing, devising appropriate research methodologies and assessing the ways in which we 'evidence' police culture in the future will become even more challenging as we begin to untangle the various cultural issues associated with the increased complexity of 'policing' and its contexts. 


\section{REFERENCES}

Abbott, A. (1991). History and sociology: The lost synthesis. Social Science History 15, 201-238.

Altbeker, A. (2005). The dirty work of democracy: A year on the streets with the SAP. Cape Town: Jonathan Ball Publishers.

Banton, M. (1964). The Policeman in the Community. London: Tavistock

Beal, C. (2001). Thank God for police culture. Police Journal Online 82.

Beckford, J. (1975). The trumpet of prophecy: A sociological study of Jehovah's Witnesses. Oxford: Basil Blackwell.

Bittner, E. (1967). The police on skid-sow: A study of peace-keeping. American Sociological Review 32, 699-715.

Bozzoli, B. (with Nkotsoe, M). (1991) Women of Phokeng: consciousness, life strategy and migrancy in South Africa: 1900-1983. London: James Currey

Brogden, M. (1982). The police: Autonomy and consent. London: Academic Press

Brogden, M. (1991). On the Mersey beat: An oral history of policing Liverpool between the wars. Oxford: Oxford University Press. 
Brown, A. (1995). Organisational culture. London: Pitman Publishing.

Chan, J. (1997). Changing police culture: Policing in a multicultural society. Cambridge: Cambridge University Press.

Emsley, C. (2005). Sergeant Goddard: The story of a rotten apple, or a diseased orchard? In A.G Srebnick. and R. Lévy, (Eds.), Crime and culture: An historical perspective (pp. 86-104). Aldershot: Ashgate.

Ericson, R.V., Baranek, P.M., and Chan, J.B.L. (1987). Visualizing deviance: A study of news organization. Toronto: University of Toronto Press.

Fielding, N. (1997). Review of Chan, J. (1997) Changing police culture: policing in a multicultural society. Sociological Research Online 2.

Foster, J. (2003). Police cultures. In T.Newburn (Ed.) Handbook of policing (pp. 196-227). Cullompton: Willan

Frisch, M. (1990). A shared Authority: Essays on the craft and meaning of oral and public history. Albany, New York: State University of New York Press.

Garland, D. (2001). The culture of control. Oxford: Oxford University Press.

Gennete, G. (1980). Narrative discourse. Oxford: Basil Blackwell. 
Goldstein, H. (1979). Improving policing: A problem-oriented approach. Crime and Delinquency 25, 236-258.

Goodey, J. (2000). Biographical lessons for criminology. Theoretical criminology 4, 473-498.

Grele, R.J. (1996). Directions for oral history in the United States. In D.K. Dunaway and W.K. Baum (Eds.), Oral history: An interdisciplinary anthology (pp.62-84). Walnut Creek: Altamira Press

Grele, R.J (1998). Movement without aim: Methodological and theoretical problems in oral history. In R. Perks and A.Thomson (Eds.), The oral history reader (pp. 3852). London: Routledge.

Hackney WEA (1975) Volume 1: 1905-1945: A people's autobiography of Hackney, Hackney: WEA.

HMIC (1999). Winning the race-revisited: A follow up to the HMIC thematic inspection report on police community and race relations (1998/1999). London: HMSO.

Howgrave-Graham, H.M. (1947). The metropolitan police at war. London: HMSO. 
Kennedy, E. L. (1998). Telling tales: oral history and the construction of preStonewall lesbian history. In R. Perks and A. Thomson (Eds.), The oral history reader (pp.344-355). London, Routledge.

Library of Congress. (1971). National union catalogue of manuscript collections: Information circular No. 7. Washington, DC. : Library of Congress, Descriptive Cataloging Division, Manuscript Section.

Loader, I. and Mulcahy, A. (2003) Policing and the condition of England: Memory, politics and culture. Oxford: Oxford University Press.

Loader, I. and Sparks, R. (2005). For an historical sociology of crime policy in England and Wales since 1968. In M. Matravers (Ed.), Managing modernity: politics and the culture of control (pp. 5-32). Abingdon: Routledge.

Lummis, T. (1983). Structure and validity in oral evidence. International Journal of Oral History 2, 109-120.

MacAlister, D. (2004). Canadian police subculture. In S. Nancoo (Ed.), Contemporary issues in Canadian policing (pp. 157-198). Mississauga, Ontario: Canadian Educators' Press.

Manning, P. (1978a). Mandate, strategies and appearance. In P. Manning and J. Van Maanen (Eds.), Policing: A view from the street (pp. 7-31). Santa Monica: Goodyear. 
Manning, P.K. (1978b). Lying, secrecy and social control. In P. Manning and J. Van Maanen (Eds.), Policing: A view from the street (pp. 238-255). Santa Monica: Goodyear.

Manning, P. (1989). Occupational culture. In W. G. Bailey (Ed.), The encyclopedia of police science (pp. 360-363). New York: Garland.

Marks, M. (2005). Transforming the robocops: Changing Police in South Africa. Durban: University of Kwazulu-Natal Press.

Matravers, A. and Maruna, S. (2005). Contemporary penality and psychoanalysis. In M. Matravers (Ed.), Managing modernity: politics and the culture of control (pp. 118-144). Abingdon: Routledge.

Narayanan, G. (2005). Theorizing police response to domestic violence in the Singaporean context: Police subculture revisited. Journal of Criminal Justice 33, 429-439.

Newburn, T. (2003). The future of policing. In T.Newburn (Ed.), Handbook of policing (pp. 707-721). Cullompton: Willan.

Perks, R. and Thomson, A. (1998) (Eds.) Introduction. In R. Perks and A. Thomson (Eds.), The oral history reader (pp. ix-xiii). London: Routledge. 
Popular Memory Group. (1982). Popular memory: theory, politics, method. In R. Johnson, G. McLennan, B. Schwarz and D. Sutton. (Eds.), Making histories: studies in history-writing and politics (pp. 205-252). London, Hutchinson.

Portelli, A. (1991). The death of Luigi Trastulli and other stories: Form and meaning in oral history. Albany, New York: State University of New York Press.

Punch, M. (1985). Conduct unbecoming: The social construction of police deviance and control. London: Tavistock.

Reiner, R. (1992). The politics of the police (2nd edition). London: Harvester Wheatsheaf.

Reiner, R. (2000). The politics of the police (3rd edition). Oxford: Oxford University Press.

Samuel, R. (1976). Local history and oral history. History Workshop: A Journal of Socialist Historians 1, 191-208.

Selbourne, D. (1980). On the methods of history workshop. History Workshop: A Journal of Socialist Historians 9, 150-161.

Seldon, A. and Pappworth, J. (1983). By word of mouth: Elite oral history. London: Methane. 
Shearing, C.D. and Ericson, R.V. (1991). Culture as figurative action. British Journal of Sociology 42, 481-506.

Skolnick, J. (1994). Justice without trial: Law enforcement in democratic society ( ${ }^{\text {rd }}$ edition). London: Wiley.

Starr, L. (1977). Oral history. In A. Kent. H. Lancour and J.E. Daily (Eds.) Encyclopedia of Library and Information Science, 20, p.440, New York: M. Dekker

Susman, W.I. (1964). History and the American intellectual: Uses of a usable past. American Quarterly 16, 243-263.

Thomson, A. (1998). Anzac memories: Putting popular memory theory into practice in Australia. In R. Perks and A. Thomson (Eds.), The oral history reader (pp. 300-310). London: Routledge.

Van der Spuy (2006) Review of Altbeker, A. (2005). The dirty work of democracy: A year on the streets with the SAP, and Marks, M. (2005). Transforming the robocops: Changing Police in South Africa. British Journal of Criminology 46, $762-765$

Van Patten, I.T. and Burke, T. W. (2001) Critical incident stress and the child homicide inspector. Homicide Studies 5 (2), 131-152. 
Vollmer, A. (1936). The police and modern society. Berkeley: University of California Press.

Waddington, P. A. J. (1999). Police (canteen) sub-culture: An appreciation. British Journal of Criminology 39, 287-309.

Walmsley, J. (1995). Life history interviews with people with learning disabilities. Oral History 23, 71-77.

Weinberger, B. (1995). The best police in the world: An oral history of English policing. Hampshire: Scolar.

Westley, W.A. (1970). Violence and the police: A sociological study of law, custom and morality. Cambridge, Mass. : MIT. 
KEY WORDS: police culture, definitions of police culture, oral history, narratives, research methodology. 
Address/Email Address

Dr Tom Cockcroft

Department of Crime and Policing Studies

Canterbury Christ Church University

North Holmes Road

Canterbury

Kent CT1 1 QU

Tel. (01227) 782171

Email: tc56@canterbury.ac.uk 